\title{
KINERJA PORTOFOLIO SAHAM BERDASARKAN UKURAN PERUSAHAAN
}

\author{
Ni Luh Putu Mita Dani Puspita ${ }^{1}$ \\ Ni Ketut Purnawati ${ }^{2}$ \\ ${ }^{1,2}$ Fakultas Ekonomi dan Bisnis Universitas Udayana (Unud), Bali, Indonesia \\ email: mithadanipuspita@yahoo.com
}

\begin{abstract}
ABSTRAK
Ketidaksesuaian harga saham merupakan bentuk dari tidak efisiensinya pasar. Terdapat ketidaksesuaian harga saham berkaitan dengan ukuran perusahaan memperlihatkan saham perusahaan kecil memberikan return yang lebih besar dibandingkan dengan perusahaan besar. Tujuan penelitian ini untuk mengukur dan membandingkan kinerja portofolio saham perusahaan berukuran besar dengan portofolio saham perusahaan berukuran kecil. Penelitian ini membandingkan kinerja portofolio saham yang dikukur dengan indeks Sharpe dan sampel yang digunakan yaitu saham perusahaan yang konsisten masuk ke dalam Indeks Kompas 100 periode 2012-2017. Analisis yang digunakan yaitu uji beda dua rata-rata independen. Hasil menunjukkan kinerja portofolio saham ukuran besar lebih tinggi dibandingkan portofolio saham ukuran kecil dan tidak terdapat perbedaan yang signifikan antara kinerja portofolio saham ukuran besar dengan portofolio saham ukuran kecil. Penelitian ini dapat membantu investor dalam mengambil keputusan dengan melihat kinerja portofolio saham. Investor dapat memilih perusahaan besar maupun perusahaan kecil karena tidak ada perbedaan yang signifikan antara kinerja portofolio saham ukuran besar dengan portofolio saham ukuran kecil.

Kata kunci : ukuran perusahaan, kinerja perusahaan, indeks Sharpe
\end{abstract}

\begin{abstract}
Mismatch of stock prices is form of market inefficiency. Mismatch of stock prices related to the size of the company showing the shares of small companies provide greater returns compared to large companies. The purpose of this study to measure and compare performance of large-sized with small-sized company stock portfolios. This study compares the performance of stock portfolios measured by the Sharpe index and the samples used, namely company stocks that consistently enter the Kompas 100 Index in 2012-2017. The analysis used is a different test of two independent averages. The results show that the performance of a large-size stock portfolio is higher than a small-size stock portfolio and there is no significant difference between the performance of a large-size stock portfolio and a small stock portfolio. This research can help investors make decisions by looking at performance of stock. Investors can choose large companies and small companies because there is no significant difference between the performance of large-size and small-size stock portfolios.
\end{abstract}

Keywords: company size, company performance, Sharpe index 


\section{PENDAHULUAN}

Pasar modal merupakan tempat berbagai pihak, khususnya perusahaan untuk berbagi instrumen keuangan jangka panjang dalam bentuk modal maupun hutang. Fungsi dari pasar modal yaitu memindahkan dana dari pihak yang mempunyai kelebihan dana (lenders) ke pihak yang membutuhkan dana (borrowers). (Pradnyaparamita, 2017). Lenders berharap dengan menginvestasikan dana yang mereka miliki akan memperoleh imbalan dari penyerahan dana tersebut, sedangkan borrowers memungkinkan untuk melakukan investasi dengan dana yang sudah diberikan oleh pihak luar tanpa harus menunggu tersedianya dana dari hasil operasi perusahaan. Pada pasar modal memungkinkan perusahaan untuk menerbitkan sekuritas berupa surat tanda kepemilikan (saham) atau surat tanda hutang (obligasi) untuk menghindari perusahaan dari kondisi rasio hutang dengan modal yang terlalu tinggi.

Perusahaan dapat menghimpun dana dari investor dengan cara menerbitkan dan menjual saham atau obligasi dan inverstor sebagai pihak yang mempunyai kelebihan dana dapat menginvestasikan dana mereka di perusahaan, tentunya tujuan investor menginvestasikan dana yang mereka miliki yaitu untuk mendapatkan keuntungan dari hasil investasi tersebut (Yani, Suadarma, \& Prihatiningtias, 2014).

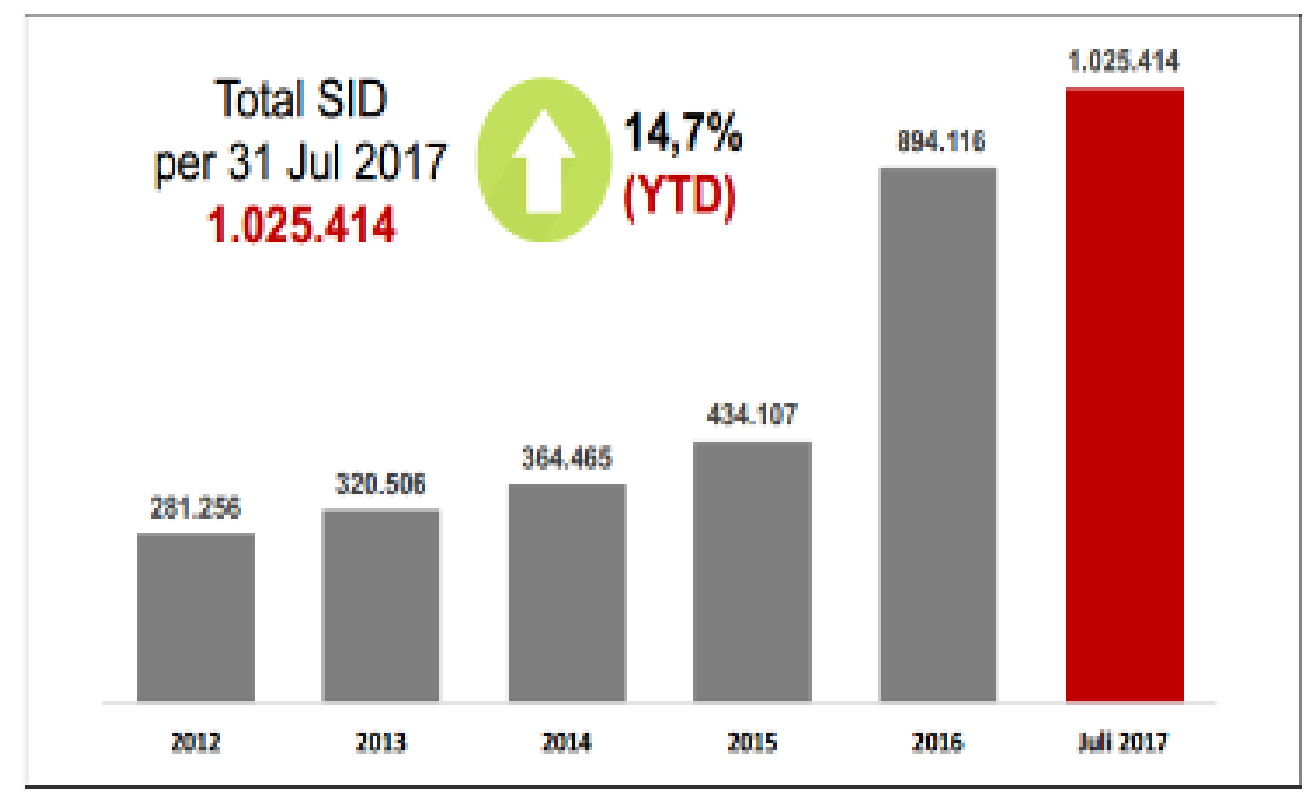

\section{Gambar 1. Pertumbuhan Single Investor Identification (SID) Tahun 2012- Juli 2017}

Sumber: Data diolah, 2019

Minat terhadap investasi di pasar modal Indonesia dapat dikatakan cukup tinggi, menurut Berita Pers PT Kustodian Sentral Efek Indonesia (KSEI) tahun 2017, tercatat jumlah investor yang melakukan investasi mengalami peningkatan yang cukup tajam hingga menembus angka lebih dari 1 juta investor per Juli 2017. 
Salah satu investasi yang menjadi sorotan masyarakat yaitu investasi saham. Saham merupakan tanda bukti penyertaan kepemilikan modal atau dana pada suatu perusahaan.

Komposisi kepemilikan saham oleh investor lokal dari tahun 2016 sampai Juli 2017 mengalami kenaikan sebesar 11\%, karena kemudahan dalam melakukan investasi menyebabkan meningkatnya keinginan untuk berinvestasi saham, selain itu saham juga mampu memberikan tingkat keuntungan yang lebih menarik. Berikut merupakan data jumlah investor di Indonesia tahun 2012-2017 dan data komposisi kepemilikan saham investor lokal dan investor asing.

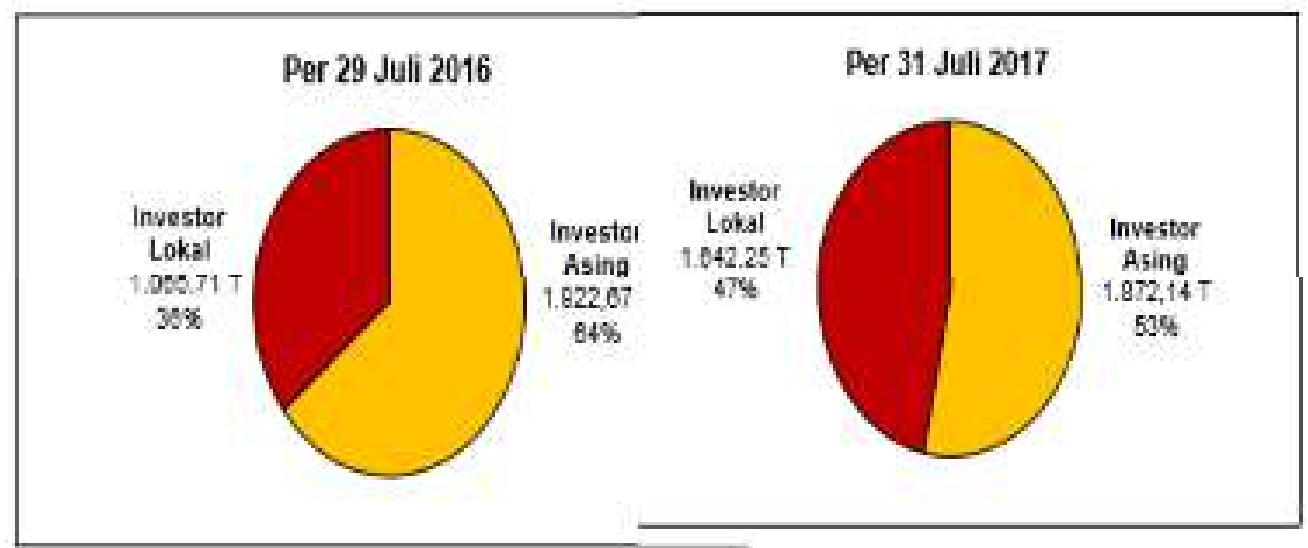

Gambar 2. Komposisi Kepemilikan Saham (dalam Triliun Rupiah)

Sumber: Data diolah, 2019

Investor dalam berinvestasi saham akan mengharapkan keuntungan dan juga akan dihadapkan pada risiko dari investasi tersebut. Keuntungan dari investasi saham yaitu dividen merupakan pembagian keuntungan yang diberikan kepada investor berdasarkan banyaknya saham yang dimiliki investor dan berasal dari laba perusahaan serta capital gain merupakan selisih antara harga jual saham dengan harga beli saham (Yulia \& Artini, 2015). Selain keuntungan, investor juga dihadapkan pada risiko dalam berinvestasi saham, yaitu capital loss yaitu kerugian yang terjadi ketika investasi mengalami penurunan nilai serta risiko likuiditas yaitu perusahaan yang sahamnya dimiliki investor dinyatakan bangkrut (Handayani, 2014).

Jika investor ingin mendapatkan keuntungan dalam berinvestasi, investor tentunya harus melakukan strategi guna mendapatkan keuntungan (return) yang maksimal dan risiko (risk) yang seminimal mungkin. Strategi yang dapat dilakukan oleh investor yaitu dengan membentuk portofolio dan melakukan penilaian kinerja terhadap portofolio tersebut. Portofolio merupakan kumpulan dari beberapa sekuritas yang diinvestasikan dan dimiliki oleh investor, baik investor lembaga maupun investor perorangan (Saputro \& Badjra, 2016).

Ada dua strategi yang dapat dilakukan investor dalam pembentukan portofolio saham, yaitu strategi pasif dan strategi aktif. Strategi pasif yaitu investor tidak akan berusaha untuk aktif melakukan penjualan dan pembelian saham yang 
bisa menghasilkan abnormal return. Strategi pasif juga hanya mendasarkan pergerakan harga saham pada pergerakan indeks pasar, sedangkan strategi aktif yaitu investor cenderung aktif dalam mencari informasi mengenai saham yang dimilikinya, melakukan pemilihan saham dengan melakukan analisis fundamental dan teknikal, melakukan penjualan dan pembelian saham secara berkala atau rutin, serta mengikuti pergerakan harga saham untuk menghasilkan abnormal return.

Informasi-informasi yang telah didapat oleh investor akan mempengaruhi harga saham dan mengakibatkan kemungkinan pergeseran ke harga equilibrium baru sehingga hal ini juga akan berpengaruh terhadap return saham. Harga equilibrium baru terbentuk akibat respon pasar terhadap informasi yang ada, dimana harga saham-saham yang diperdagangkan telah menggambarkan seluruh informasi yang relevan. Konsep ini dikenal dengan konsep pasar modal efisien. Konsep pasar modal efisien menyatakan apabila informasi tidak diserap dengan baik oleh investor maka hal tersebut akan menyebabkan ketidaksesuaian harga saham. Ketidaksesuaian harga saham merupakan bentuk dari tidak efisiensinya pasar dan kondisi ini akan memberikan peluang kepada investor untuk mendapatkan abnormal return.

Adanya ketidaksesuaian harga dibuktikan dengan penelitian terdahulu oleh Banz diantaranya berkaitan dengan ukuran perusahaan. Banz menemukan bahwa perusahaan-perusahaan di New York Stock Exchange (NYSE) yang berukuran kecil memiliki kinerja yang lebih baik atau memberikan return yang lebih besar dibandingkan dengan perusahaan-perusahaan besar, karena berbagai risiko akan dihadapi oleh perusahaan kecil. Adapun penelitian lain yang mendukung hasil dari penelitian yang dilakukan oleh Banz yaitu penelitian yang dilakukan oleh (Gautama, 2017), (Duy \& Phuoc, 2016), Pandey \& Sehgal (2015), Haq \& Rashid (2014) Ahmad et al. (2013), Ye \& Li (2013) dan Rutledge et al. (2008) yang menunjukkan bahwa perusahaan ukuran besar cenderung memiliki kinerja yang lebih rendah atau memberikan return yang lebih sedikit dibandingkan dengan perusahaan ukuran kecil.

Terdapat juga penelitian lain yang bertolak belakang yaitu penelitian yang dilakukan oleh Chiang (2016), Zaheri \& Barkhordary (2015), Latjuba \& Pasaribu (2013) yang menunjukkan bahwa perusahaan ukuran besar cenderung memiliki kinerja yang lebih baik atau memberikan return yang lebih besar dibandingkan dengan perusahaan ukuran kecil. Investor tentunya lebih memilih untuk membeli saham-saham yang memiliki kinerja baik dan menjual saham-saham yang memiliki kinerja buruk. Pembelian saham-saham yang memiliki kinerja baik akan terus meningkatkan kinerja dari saham tersebut, sehingga peningkatan kinerja saham bisa dijadikan sinyal positif bagi investor untuk melakukan investasi di masa yang akan datang (Saputro \& Badjra, 2016). Perbedaan-perbedaan dari hasil penelitian sebelumnya menjadi dasar alasan mengapa penelitian ini dilakukan, selain itu perhitungan kinerja portofolio saham berdasarkan ukuran perusahaan jarang digunakan dalam penelitian, seperti pada beberapa penelitian yang dilakukan oleh Salamat \& Mustafa (2016), Taha \& Elgizir (2016), Alioui et al. (2015), dan Tahir et al. (2013) yang menggunakan kapitalisasi pasar dalam pembentukan portofolio saham untuk menghitung kinerja portofolio saham tersebut. 
Saham-saham yang termasuk ke dalam Indeks Kompas 100 di Bursa Efek Indonesia periode 2012-2017 digunakan pada penelitian ini dengan melihat kinerja portofolio yang dibentuk berdasarkan ukuran perusahaan karena ukuran perusahaan merupakan indikator yang menunjukkan kekuatan finansial suatu perusahaan, dimana ukuran perusahaan menggambarkan besar kecilnya perusahaan dan salah satunya dapat dilihat dari besarnya total aset perusahaan (Denziana \& Monica, 2016). Indikator total aset dapat digunakan sebagai salah satu strategi investor dalam membentuk portofolio saham. Penggunaan Indeks Kompas 100 dalam penelitian ini karena pada indeks tersebut terdapat berbagai macam sektor perusahaan sehingga akan meminimalisir risiko yang akan dihadapi oleh investor, selain itu saham yang masuk ke dalam Indeks Kompas 100 memiliki likuiditas tinggi, kapitalisasi pasar besar serta memiliki fundamental dan kinerja yang baik.

Berdasarkan latar belakang masalah yang sudah dijelaskan, maka tujuan yang ingin dicapai dalam penelitian ini : 1) Untuk menganalisis kinerja portofolio saham ukuran besar pada Indeks Kompas 100. 2) Untuk menganalisis kinerja portofolio saham ukuran kecil pada Indeks Kompas 100. 3) Untuk menguji signifikansi perbedaan antara kinerja portofolio saham ukuran besar dibandingkan dengan portofolio saham ukuran kecil.

Penelitian ini diharapkan dapat memberikan kontribusi empiris pada manajemen investasi tentang kinerja portofolio saham yang dibentuk berdasarkan ukuran perusahaan pada Indeks Kompas 100 di Bursa Efek Indonesia periode 20122017 serta dapat memberikan informasi kepada para investor dalam melakukan investasi saham dan digunakan sebagai bahan pertimbangan dalam mengambil keputusan investasi dengan melihat kinerja portofolio saham sehingga mendapatkan keuntungan dan strategi yang digunakan lebih tepat.

Investasi merupakan komitmen atas sejumlah uang atau dana dengan harapan memperoleh keuntungan di masa yang akan datang. Terdapat dua jenis investasi yaitu investasi pada aset real yang meliputi emas, tanah, mesin maupun bangunan dan investasi keuangan yang meliputi deposito, obligasi maupun saham. Penyebaran dana ke berbagai aset yang berbeda merupakan cara untuk mengurangi risiko dalam berinvestasi, sehingga jika satu aset mengalami kerugian, maka nilai investasi tidak akan hilang semua.

Teori portofolio menyebutkan bahwa risiko investasi dipisahkan menjadi dua jenis risiko yaitu risiko sistematis dan risiko tidak sistematis. Risiko sistematis tidak dapat dihilangkan dengan melakukan diversifikasi karena risiko dipengaruhi oleh kondisi makro yang dapat mempengaruhi pasar secara keseluruhan. Risiko tidak sistematis dapat dihilangkan dengan melakukan diversifikasi karena risiko dipengaruhi oleh kondisi mikro atau karena risiko hanya ada dalam satu industri atau perusahaan. Manajemen portofolio menyebutkan bahwa diversifikasi aset dalam suatu portofolio dapat meminimalisir risiko. Teori portofolio berkaitan dengan estimasi investor terhadap ekspektasi risiko dan return dengan mengkombinasi aset ke dalam diversifikasi portofolio. Hal ini juga berlaku dalam investasi saham, jika berinvestasi saham sebaiknya tidak hanya pada satu saham, tetapi beberapa saham dan berbagai industri. Berdasarkan konsep portofolio, semakin banyak jumlah saham dan semakin bervariasi industri yang dimasukkan dalam portofolio, semakin besar manfaat pengurangan risiko. 
Pasar yang harga sekuritas-sekuritasnya menggambarkan seluruh informasi yang relevan merupakan ciri-ciri dari pasar modal efisien. Pasar efisien akan cepat bereaksi dengan adanya informasi baru yang tersedia, pasar akan bergerak dan dengan cepat menyesuaikan dengan nilai informasi yang ada sehingga mencapai harga keseimbangan baru. Semakin efisien pasar, maka investor akan memiliki kemungkinan kecil untuk mendapatkan return tak normal (abnormal return).

Pasar modal dapat dikatakan sebagai pasar modal efisien apabila memenuhi kondisi, yaitu terdapat banyak investor yang rasional dan investor berusaha untuk mendapatkan profit yang maksimal serta berperan aktif untuk berpartisipasi dalam pasar, seperti melakukan analisis, penilaian, dan melakukan perdagangan sekuritas. Pada saat yang sama, seluruh pelaku pasar baik itu pihak yang memiliki dana maupun pihak yang membutuhkan dana memperoleh informasi dengan cara yang murah dan mudah. Informasi pasar bersifat random, yaitu informasi yang ada pada saat ini belum tentu sama dengan informasi yang ada pada masa yang akan datang. Reaksi cepat dari para investor terhadap informasi baru menyebabkan perubahan cepat terhadap harga sekuritas sesuai dengan perubahan nilai akibat dari informasi yang ada.

Pasar efisien memiliki bentuk-bentuk yang dapat ditinjau dari segi ketersediaan informasi dan pengambilan keputusan. Pasar efisien yang berhubungan dengan informasi disebut dengan pasar efisien secara informasi (informationally efficient market) sedangkan pasar efisien yang berhubungan dengan keputusan disebut dengan pasar efisien secara keputusan (decisionally efficient market). Kunci utama untuk mengukur pasar efisien secara informasi yaitu melihat hubungan antara harga sekuritas dengan informasi yang akan mempengaruhi harga sekuritas. Pasar efisien bentuk lemah memiliki karakteristik harga sekuritas sepenuhnya menggambarkan informasi yang ada pada masa lalu. Semua informasi yang ada pada masa lalu (historis) akan tercermin dalam harga yang terbentuk pada masa sekarang. Investor tidak akan bisa menggunakan informasi pada masa lalu untuk memprediksi harga pada masa yang akan datang (random walk theory). Oleh karena itu, informasi historis seperti harga, volume perdagangan, dan peristiwa masa lalu mencerminkan harga pada masa sekarang dan tidak dapat digunakan untuk memprediksi harga pada masa yang akan datang. Pada pasar efisien ini, tidak ada investor yang dapat menggunakan informasi harga pada masa lalu untuk memprediksi nilai pasar sekuritas pada masa yang akan datang.

Pasar efisien bentuk setengan kuat merupakan keadaan dimana harga sekuritas menggambarkan informasi pada masa lalu (historis) dan informasi yang dipublikasikan seperti laporan keuangan yang akan berdampak pada aliran kas suatu perusahaan pada masa yang akan datang. Pada bentuk pasar efisien ini, abnormal return terjadi di seputaran pengumuman suatu peristiwa dan pasar menyerap serta merespon informasi dengan cepat selama kurun waktu satu sampai dua hari di seputar pengumuman. Jika pasar memiliki respon yang lambat terhadap informasi, maka pasar tidak efisien dalam bentuk setengah kuat.

Pasar efisien bentuk kuat merupakan keadaan dimana harga sekuritas menggambarkan informasi pada masa lalu (historis), informasi yang dipublikasikan, dan informasi yang tidak dipublikasikan atau informasi privat. Pada pasar efisien ini, tidak ada investor yang dapat menggunakan informasi untuk 
mendapatkan abnormal return. Untuk mengetahui kebenaran hipotesis pasar modal efisien, yaitu pasar efisien bentuk lemah, pasar efisien bentuk setengah kuat, dan pasar efisien bentuk kuat, maka dilakukan pengujian untuk masing-masing bentuk tersebut. (Yanuarta, 2012).

Pengujian bentuk lemah dilakukan dengan pengujian prediktabilitas return yang meliputi pengujian pola return (harian, mingguan atau bulanan), dan pengujian hubungan return dengan karakterisik perusahaan. Pengujian bentuk setengah kuat dilakukan dengan event study yang bertujuan untuk mengamati perubahan harga saham terhadap adanya informasi baru. Pengujian bentuk kuat dilakukan dengan pengujian private information.

Kecanggihan pelaku pasar dalam mengolah informasi untuk mengambil keputusan menggambarkan pasar efisien secara keputusan. Adapun beberapa jenis informasi, yaitu informasi yang tidak perlu diolah dan informasi yang perlu diolah. Contoh informasi yang tidak perlu diolah yaitu kenaikan penjualan dan laba ditahan, sedangkan contoh informasi yang masih perlu diolah yaitu akuisisi dan merger. Semua pelaku pasar akan menerima informasi yang perlu diolah pada saat diumumkan, tetapi harga sekuritas belum tentu mencerminkan informasi secara penuh karena diperlukan analisis dan interpretasi sebagai kabar buruk (bad news) atau kabar baik (good news). Oleh karena itu diperlukan kecanggihan (sophisticated) pelaku pasar untuk mengolah informasi tersebut. Investor yang memiliki kecanggihan kemungkinan akan mendapatkan return tak normal (abnormal return), karena investor tersebut dapat menganalisis dan menginterpretasikan informasi dengan benar dan tepat. Dengan demikian diperlukan kecanggihan pelaku pasar dalam mengolah informasi yang ada untuk mengambil keputusan.

Investor dalam melakukan pembentukan portofolio saham dapat menerapkan dua strategi, yaitu strategi pasif dan strategi aktif. Strategi pasif yaitu investor tidak akan berusaha untuk aktif melakukan penjualan dan pembelian saham yang bisa menghasilkan abnormal return. Strategi pasif juga hanya mendasarkan pergerakan harga saham pada pergerakan indeks pasar, sedangkan strategi aktif yaitu investor cenderung aktif dalam mencari informasi mengenai saham yang dimilikinya, melakukan pemilihan saham dengan melakukan analisis fundamental dan teknikal, melakukan penjualan dan pembelian saham secara berkala atau rutin, serta mengikuti pergerakan harga saham untuk menghasilkan abnormal return.

Evaluasi kinerja perlu dilakukan pada portofolio yang telah dibentuk oleh investor. Evaluasi ini terkait dengan dua isu utama, yaitu (1) return portofolio yang telah dibentuk pada periode formasi dievaluasi apakah mampu memberikan return yang melebihi return portofolio lainnya yang dijadikan pembanding (benchmark), dan (2) return yang diperoleh dievaluasi apakah sudah sesuai dengan tingkat risiko yang telah ditanggung. Pengukuran kinerja portofolio dapat dilakukan dengan mengukur tingkat return portofolio saham dan tingkat risiko portofolio saham. Tingkat return portofolio dapat dihitung dengan cara menjumlahkan seluruh aliran kas yang diterima, termasuk pendapatan bunga selama periode investasi dengan selisih perubahan nilai pasar portofolio (capital gain/loss) dan penjumlahan deviden, kemudian dibagi dengan nilai pasar portofolio awal periode. 
Metode perhitungan tersebut mengandung kelemahan karena hanya sesuai digunakan untuk menghitung tingkat return portofolio yang memiliki sifat statis, yaitu portofolio yang tidak mempunyai aliran kas masuk maupun aliran kas keluar dari investor. Terkadang asumsi ini tidak sesuai dengan kenyataan yang biasanya terjadi. Kenyataan yang terjadi yaitu investor selama periode investasi bisa saja melakukan penarikan atau penambahan dana dari portofolio yang telah dibentuk oleh investor, maka diperlukan metode-metode perhitungan tingkat return portofolio yang lebih tepat dan dapat mengakomodasi situasi tersebut. Metode perhitungan return portofolio yang digunakan yaitu time weighted rate of return (TWR) dan dollar weighted rate of return (DWR). TWR digunakan untuk mengukur besarnya tingkat return yang ditawarkan oleh portofolio yang dimiliki investor. Penarikan atau penambahan dana yang dilakukan investor selama periode perhitungan return portofolio tidak mempengaruhi besarnya TWR.

Return yang benar-benar diterima oleh investor disebut dollar weighted rate of return (DWR). Berbeda dengan TWR, besarnya penarikan atau penambahan dana yang dilakukan investor selama periode perhitungan return portofolio akan mempengaruhi DWR. Tingkat return portofolio akan dihitung setiap terjadi aliran kas masuk (penambahan dana) dan aliran kas keluar (penarikan dana) selama periode pengukuran. Lalu compound rate of return untuk keseluruhan periode pengukuran ditentukan melalui perhitungn tersebut.

Metode yang lebih sesuai digunakan oleh investor yaitu metode DWR, karena metode ini bisa menjawab pertanyaan mengenai besarnya return yang akan diterima oleh investor, sedangkan metode yang lebih sesuai digunakan oleh manajer investasi yaitu metode TWR, karena metode ini bisa menjawab pertanyaan mengenai besarnya return yang ditawarkan portofolio. Perhitungan lainnya yang dapat digunakan untuk mengukur kinerja portofolio saham yaitu dengan menghitung abnormal return. Abnormal return adalah selisih antara return aktual dengan return harapan. Mengestimasi return harapan adalah dengan menggunakan model estimasi mean adjusted return, market adjusted return, dan market model return.

Kinerja sebuah portofolio tidak hanya dapat dilihat dari tingkat return yang dihasilkan, tetapi tingkat risiko dari portofolio tersebut juga harus diperhatikan. Terdapat tiga ukuran kinerja portofolio yang sudah memasukkan return dan risiko ke dalam perhitungannya, yaitu indeks Sharpe, indeks Treynor, dan indeks Jensen. Perhitungan indeks Sharpe didasarkan pada konsep capital market line (garis pasar modal) sebagai patok duga (benchmark), yaitu dengan cara membagi premi risiko portofolio dengan standar deviasinya.

Indeks Treynor didasarkan pada konsep security market line (garis pasar sekuritas) sebagai pembanding (benchmark) dan menggunakan asumsi bahwa portofolio sudah terdiversifikasi yang berarti return portofolio hampir semuanya dipengaruhi oleh return pasar, sehingga risiko sistematis (beta) dianggap sebagai risiko yang relevan. Indeks Jensen menunjukkan perbedaan antara tingkat return aktual dengan tingkat return harapan jika portofolio tersebut berada pada garis pasar sekuritas. 


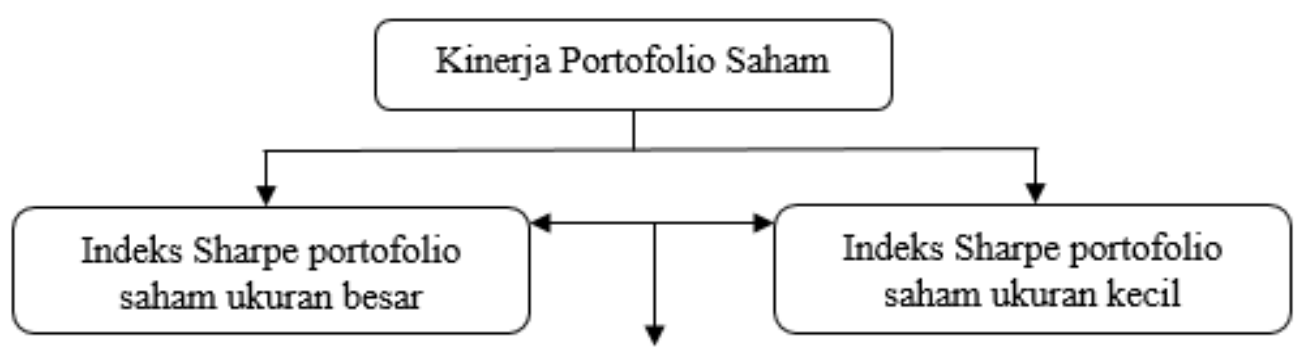

Signifikansi perbedaan

\section{Gambar 3. Kerangka Konseptual Hipotesis}

Perusahaan yang berukuran besar lebih mudah memperoleh dana di pasar modal dibandingkan dengan perusahaan berukuran kecil, karena kemudahan akses ini berarti perusahaan besar juga memiliki fleksibilitas yang lebih besar. Selain itu kekuatan tawar-menawar (bargaining power) dalam kontrak keuangan perusahaan ukuran besar cenderung lebih kuat serta adanya kemungkinan pengaruh skala dalam biaya membuat perusahaan besar dapat memperoleh laba yang lebih banyak dibandingkan dengan perusahaan kecil sehingga return yang akan diberikan perusahaan besar kepada investor menjadi lebih tinggi dibandingkan perusahaan kecil.

Penelitian terdahulu yang mendukung deskripsi teori yaitu penelitian yang dilakukan oleh Chiang (2016) pada perusahaan di Amerika selama tahun 1999 sampai dengan 2008 menunjukkan hasil bahwa ukuran perusahaan memiliki hubungan yang searah atau positif dengan return saham, artinya kinerja perusahaan besar lebih baik dibanding perusahaan kecil.

Zaheri \& Barkhordary (2015) melakukan penelitian mengenai hubungan ukuran perusahaan, price earning ratio dan profit margin terhadap return saham di Bursa Efek Teheran pada tahun 2004-2011. Hasil dari penelitian ini menunjukkan bahwa ukuran perusahaan memiliki hubungan yang positif atau searah dengan return saham, sedangkan price earning ratio dan profit margin memiliki hubungan yang negatif atau terbalik dengan return saham. Faktor yang menyebabkan adanya hubungan terbalik yaitu inefisiensinya Bursa Efek Teheran serta analisis dan keputusan yang diambil oleh investor kurang tepat akibat kurangnya pemahaman atas informasi yang diperoleh.

Latjuba \& Pasaribu (2013) melakukan penelitian mengenai ukuran perusahaan dan likuiditas dengan jumlah sampel sebanyak 45 perusahaan selama periode 2009-2011. Hasil penelitian menunjukkan bahwa ukuran perusahaan dan likuiditas memiliki hubungan yang searah terhadap return saham, hal ini disebabkan karena semakin besar perusahaan biasanya informasi yang tersedia untuk investor dalam pengambilan keputusan sehubungan dengan investasi dalam saham perusahaan tersebut semakin banyak.

Sorayaeni et al. (2012) menguji hubungan antara ukuran perusahaan dengan return yang dihasilkan di Iran dengan jumlah sampel sebanyak 104 perusahaan. Penelitian ini menunjukkan hasil bahwa ukuran perusahaan besar memiliki 
kelebihan pengembalian signifikan lebih besar dibandingkan perusahaan kecil. Hal ini disebabkan karena pasar keuangan Iran mencapai bentuk pasar efisien.

Berdasarkan uraian di atas mengenai deskripsi teori dan hasil penelitian terdahulu, maka hipotesis yang dirumuskan pada penelitian ini yaitu sebagai berikut.

$\mathrm{H}_{1} \quad$ : Terdapat perbedaan yang signifikan antara kinerja portofolio saham ukuran besar dibandingkan dengan portofolio saham ukuran kecil.

\section{METODE PENELITIAN}

Desain penelitian yang digunakan adalah desain penelitian komparatif yaitu membandingkan kinerja portofolio saham ukuran besar dengan kinerja portofolio saham ukuran kecil. Penelitian ini dilakukan pada perusahaan yang sahamnya tercatat di Bursa Efek Indonesia (BEI) dan masuk ke dalam Indeks Kompas 100 selama periode Januari 2012 sampai dengan Desember 2017 dengan obyek penelitian yaitu kinerja portofolio saham ukuran besar dan kinerja portofolio saham ukuran kecil yang dibentuk berdasarkan ukuran perusahaan dengan indikator total aset.

Variabel dalam penelitian ini adalah kinerja portofolio saham ukuran besarkecil yang diukur dengan indeks Sharpe dimana indeks Sharpe dipilih karena pembentukan portofolio tidak melihat korelasi antar saham tetapi hanya melihat ukuran saham. Risk adjusted return portofolio saham ukuran besar-kecil merupakan pengukuran kinerja portofolio yang sudah memasukkan faktor risiko yaitu indeks Sharpe portofolio saham ukuran besar-kecil pada Indeks Kompas 100 periode 2012-2017 yang dihitung dengan rumus:

$\hat{S}_{P}=\frac{\bar{R}_{P}-\overline{R F}}{\sigma_{T R}}$

Keterangan :

$\hat{S}_{P} \quad=$ Indeks Treynor portofolio saham ukuran besar atau kecil

$\bar{R}_{P} \quad=$ Rata-rata return portofolio saham ukuran besar atau kecil

$\overline{R F} \quad=$ Rata-rata tingkat return bebas risiko

$\sigma_{T R} \quad=$ Standar deviasi return portofolio saham ukuran besar atau kecil

Jenis data yang digunakan yaitu data kuantitatif yang merupakan jenis data berupa angka dan sumber data yang digunakan yaitu sumber data sekunder yang merupakan sumber data yang didapat oleh peneliti secara tidak langsung dengan menggunakan media perantara. Data-data pada penelitian ini meliputi total aset yang diperoleh dari laporan keuangan dan diakses di website Bursa Efek Indonesia (BEI) www.idx.co.id, harga saham penutupan diperoleh dari www.yahoofinance.com, dan tingkat bunga Sertifikat Bank Indonesia (SBI) diperoleh dari www.bps.go.id selama periode Januari 2012 sampai dengan Desember 2017. Populasi dari penelitian ini yaitu seluruh saham perusahaan yang 
termasuk ke dalam Indeks Kompas 100 di Bursa Efek Indonesia (BEI) periode 2012-2017.

Penelitian ini menentukan sampel dengan menggunakan metode purposive sampling, yaitu peneliti membuat kriteria-kriteria yang diinginkan dari sampel sebelum peneliti menentukan sampel, setelah itu peneliti baru bisa menentukan sampel sesuai dengan kriteria-kriteria yang telah dibuat. Kriteria sampel dalam penelitian ini yaitu saham perusahaan yang tercatat di Bursa Efek Indonesia (BEI), terdaftar secara konsisten ke dalam Indeks Kompas 100, serta saham secara konsisten masuk ke dalam portofolio saham ukuran besar dan portofolio saham ukuran kecil periode 2012-2017, sehingga pada penelitian ini diperoleh sampel sebanyak 36. Berikut merupakan rincian penentuan sampel penelitian.

Tabel 1.

Kriteria Penentuan Sampel

\begin{tabular}{clc}
\hline No. & \multicolumn{1}{c}{ Keterangan } & $\begin{array}{c}\text { Jumlah } \\
\text { Perusahaan }\end{array}$ \\
\hline 1 & $\begin{array}{l}\text { Populasi perusahaan yang pernah masuk ke dalam Indeks Kompas } \\
100 \text { selama periode 2012-2017 } \\
\text { Perusahaan yang tidak konsisten masuk ke dalam Indeks Kompas }\end{array}$ & (139) \\
& $\begin{array}{l}\text { 100 periode 2012-2017 } \\
\text { Saham perusahaan yang tidak konsisten masuk ke dalam portofolio } \\
\text { saham ukuran besar-kecil periode 2012-2017 }\end{array}$ & Jumlah Sampel \\
\hline
\end{tabular}

Sumber: Data diolah, 2019

Tabel 2.

Uji Normalitas Portofolio Saham Ukuran Besar

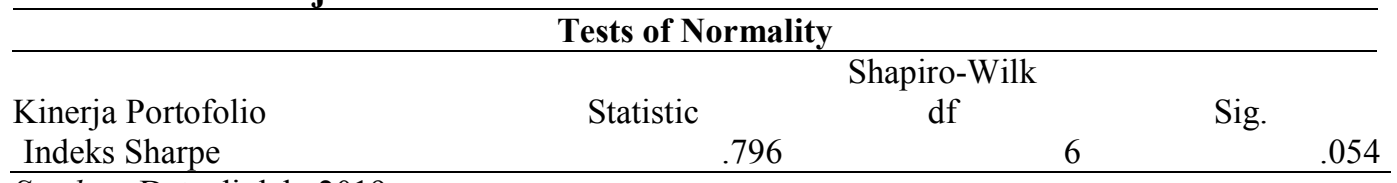

Sumber: Data diolah, 2019

Tabel 3.

Uji Normalitas Portofolio Saham Ukuran Kecil

\begin{tabular}{|c|c|c|c|c|}
\hline \multicolumn{5}{|c|}{ Tests of Normality } \\
\hline & & & & \\
\hline Kineria Portofolio & Statistic & & $\mathrm{Sig}$ & \\
\hline Indeks Sharne & 949 & 6 & & 730 \\
\hline
\end{tabular}

Sumber: Data diolah, 2019

Pengukuran kinerja portofolio dilakukan dengan membentuk portofolio saham ukuran besar dan portofolio saham ukuran kecil, kemudian dihitung indeks Sharpe dari portofolio yang telah dibentuk. Selanjutnya melakukan uji normalitas untuk mengetahui apakah data berdistribusi normal atau tidak. Uji normalitas data menggunakan pengujian Shapiro-Wilk karena jumlah data yang diuji kurang dari 50 dengan kriteria jika nilai signifikansi $>0,05$, maka data berdistribusi normal dan 
jika nilai signifikansi $<0,05$, maka data berdistribusi tidak normal. Pada penelitian ini data berdistribusi normal.

Teknik analisis statistik deskriptif dengan menentukan rentang nilai digunakan untuk menggambarkan bagaimana hasil perhitungan indeks Sharpe, apakah kinerja portofolio saham tergolong sangat baik, baik, cukup baik atau kurang baik.

Tabel 4.

Rentang Nilai Portofolio Saham Ukuran Besar

\begin{tabular}{ccc}
\hline \multirow{2}{*}{ No } & Indeks Sharpe & Kategori \\
\cline { 2 - 3 } & Rentang Nilai & Kurang Baik \\
2 & $-1,023$ s.d. $-0,641$ & Cukup Baik \\
3 & $-0,640$ s.d. $-0,258$ & Baik \\
4 & $-0,257$ s.d. 0,125 & Sangat Baik \\
\hline
\end{tabular}

Sumber: Data diolah, 2019

Tabel 5.

Rentang Nilai Portofolio Saham Ukuran Kecil

\begin{tabular}{ccc}
\hline \multirow{2}{*}{ No } & Indeks Sharpe & Kategori \\
\cline { 2 - 2 } & Rentang Nilai & Kurang Baik \\
\hline 1 & $-0,991$ s.d. $-0,579$ & Cukup Baik \\
2 & $-0,578$ s.d. $-0,166$ & Baik \\
3 & $-0,165$ s.d. 0,247 & Sangat Baik \\
4 & 0,248 s.d. 0,660 & \\
\hline
\end{tabular}

Sumber: Data diolah, 2019

Hasil perhitungan indeks Sharpe portofolio saham ukuran besar akan dibandingkan dengan portofolio saham ukuran kecil. Teknik analisis statistik uji beda dua rata-rata independen dengan menggunakan aplikasi SPSS digunakan untuk menguji signifikansi perbedaan kinerja portofolio saham ukuran besar dengan portofolio saham ukuran kecil. Hasil pengujian ini dapat memberikan bukti empiris dalam bentuk penerapan strategi investasi saham pada Indeks Kompas 100 di Bursa Efek Indonesia (BEI), dapat juga digunakan oleh investor serta manajer investasi dalam melakukan analisis investasi saham dan digunakan sebagai bahan pertimbangan dalam mengambil keputusan investasi dengan melihat kinerja portofolio saham sehingga mendapatkan keuntungan dan strategi yang digunakan lebih tepat.

Pengambilan keputusan untuk melakukan investasi dapat dengan melihat apakah terdapat perbedaan atau tidak terdapat perbedaan yang signifikan antara kinerja portofolio saham ukuran besar dengan portofolio saham ukuran kecil. Jika tidak terdapat perbedaan yang signifikan, maka investor dapat berinvestasi pada kedua portofolio. Jika terdapat perbedaan yang signifikan, maka investor dapat berinvestasi pada salah satu portofolio dengan pertimbangan return dan risiko yang akan dihadapi investor. 


\section{HASIL DAN PEMBAHASAN}

Seiring dengan meningkatnya aktivitas perdagangan, kebutuhan akan informasi yang lebih lengkap dibutuhkan oleh masyarakat, salah satunya informasi mengenai indeks harga saham sebagai cerminan dari pergerakan harga saham. PT Bursa Efek Indonesia (BEI) saat ini memiliki 22 jenis indeks harga saham yang digunakan sebagai salah satu pedoman bagi investor untuk berinvestasi di pasar modal. Salah satu indeks harga saham adalah Indeks Kompas 100. Indeks Kompas 100 merupakan indeks harga saham dari seratus saham perusahaan publik yang diperdagangkan di BEI dan secara resmi diterbitkan oleh BEI yang bekerjasama dengan harian kompas pada hari Jumat, 10 Agustus 2007. Saham yang termasuk ke dalam Indeks Kompas 100 diperkirakan mewakili 70\% sampai 80\% dari total nilai kapitalisasi pasar seluruh saham yang tercatat di BEI. Investor dapat mengamati pergerakan Indeks Kompas 100 untuk melihat kecenderungan arah pergerakan indeks.

Adanya Indeks Kompas 100, diharapkan dapat memberi manfaat bagi para investor, fund manager dan pengelola portofolio sehingga dapat digunakan sebagai acuan untuk melihat kearah mana pasar akan bergerak dan bagaimana kinerja portofolio investasinya. Selain itu, pelaku industri pasar modal akan memiliki acuan baru dalam menciptakan produk inovasi berbasis indeks. Tujuan utama BEI menetbitkan Indeks Kompas 100 yaitu menarik minat masyarakat untuk mengambil manfaat dari keberadaan BEI, baik untuk mencari pendanaan bagi perusahaan dalam mengembangkan perekonomian nasional maupun untuk investasi, serta untuk menyebarluaskan informasi pasar modal kepada masyarakat.

Saham-saham yang masuk ke dalam Indeks Kompas 100 memiliki nilai kapitalisasi pasar besar, likuiditas tinggi, dan juga merupakan saham-saham dengan fundamental dan kinerja yang baik. Adapun faktor-faktor yang digunakan untuk mempertimbangkan kriteria pemilihan saham, yaitu setiap akhir bulan Januari dan bulan Juli saham dievaluasi serta diperbaharui pada bulan Februari dan bulan Agustus. Minimal telah tercatat di BEI selama 3 bulan dan data transaksi di pasar regular selama 1 tahun terakhir digunakan untuk seleksi likuiditas, seleksi berdasarkan nilai transaksi, kapitalisasi pasar, banyaknya transaksi serta jumlah hari transaksi. Sebagai saringan terakhir, BEI melakukan evaluasi dan mempertimbangkan faktor pola perdagangan dan fundamental yang telah melewati seleksi likuiditas serta BEI bertanggungjawab penuh dalam pelaksanaan pemilihan saham yang masuk ke dalam Indeks Kompas 100 dengan mempertimbangkan kepentingan investor dan stakeholders lain dalam mengambil keputusan.

Portofolio saham ukuran besar dan portofolio saham ukuran kecil meliputi enam kali observasi selama tahun 2012-2017. Observasi pertama pada tahun 2012 membandingkan kinerja portofolio saham ukuran besar dan portofolio saham ukuran kecil yang diukur dengan indeks Sharpe, dilanjutkan sampai dengan observasi keenam pada tahun 2017.

Kinerja portofolio saham ukuran besar diukur dengan indeks Sharpe pada saham Indeks Kompas 100 tahun 2012-2017. Hasil perhitungan indeks Sharpe portofolio saham ukuran kecil dapat dilihat pada Tabel 6. 
Hasil perhitungan indeks Sharpe portofolio saham ukuran besar menunjukkan bahwa pada tahun 2013 dan 2015 portofolio saham ukuran besar memberikan return yang bernilai negatif, sedangkan pada tahun-tahun lainnya menunjukkan portofolio saham ukuran besar memberikan return yang bernilai positif. Return yang dihasilkan portofolio saham ukuran besar dilihat dari indeks Sharpe juga sangat berfluktuasi, terlihat pada Tabel 6 yang menunjukkan peningkatan dan penurunan yang cukup tinggi pada return selama tahun 2012-2017. Kinerja portofolio saham ukuran besar dilihat dari indeks Sharpe tergolong sangat baik, hal ini dapat dilihat pada Tabel 7.

Tabel 6.

Indeks Sharpe Portofolio Saham Ukuran Besar Tahun 2012-2017

\begin{tabular}{cc}
\hline Tahun Observasi & Indeks Sharpe \\
\hline 2012 & 0,503 \\
2013 & $-0,315$ \\
2014 & 0,275 \\
2015 & $-1,023$ \\
2016 & 0,420 \\
2017 & 0,487 \\
\hline
\end{tabular}

Sumber: Data diolah, 2019

Tabel 7.

Rentang Nilai Indeks Sharpe Portofolio Saham Ukuran Besar

\begin{tabular}{cccc}
\hline \multirow{2}{*}{ No } & \multicolumn{2}{c}{ Indeks Sharpe } & \multirow{2}{*}{ Kategori } \\
\cline { 2 - 3 } & Rentang Nilai & Tahun & Kurang Baik \\
\hline 1 & $-1,023$ s.d. $-0,641$ & 2015 & Cukup Baik \\
2 & $-0,640$ s.d. $-0,258$ & 2013 & Baik \\
3 & $-0,257$ s.d. 0,125 & - & Sangat Baik \\
4 & 0,126 s.d. 0,508 & $2012,2014,2016,2017$ & \\
\hline
\end{tabular}

Sumber: Data diolah, 2019

Kinerja portofolio saham ukuran kecil diukur dengan indeks Sharpe pada saham Indeks Kompas 100 tahun 2012-2017. Hasil perhitungan indeks Sharpe portofolio saham ukuran kecil dapat dilihat pada Tabel 8.

Hasil perhitungan indeks Sharpe portofolio saham ukuran kecil menunjukkan bahwa pada tahun 2013, 2015 dan 2017 portofolio saham ukuran kecil memberikan return yang bernilai negatif, sedangkan pada tahun-tahun lainnya menunjukkan portofolio saham ukuran kecil memberikan return yang bernilai positif. Return yang dihasilkan portofolio saham ukuran kecil juga sangat berfluktuasi, terlihat pada Tabel 8 yang menunjukkan peningkatan dan penurunan yang cukup tinggi pada return selama tahun 2012-2017. Kinerja portofolio saham ukuran kecil dilihat dari indeks Sharpe tergolong cukup baik, hal ini dapat dilihat pada Tabel 9. 
Tabel 8.

Indeks Sharpe Portofolio Saham Ukuran Kecil Tahun 2012-2017

\begin{tabular}{cc}
\hline Tahun Observasi & Indeks Sharpe \\
\hline 2012 & 0,551 \\
2013 & $-0,454$ \\
2014 & 0,125 \\
2015 & $-0,991$ \\
2016 & 0,656 \\
2017 & $-0,318$ \\
\hline
\end{tabular}

Sumber: Data diolah, 2019

Tabel 9.

Rentang Nilai Indeks Sharpe Portofolio Saham Ukuran Kecil

\begin{tabular}{cccc}
\hline \multirow{2}{*}{ No } & \multicolumn{2}{c}{ Indeks Sharpe } & \multirow{2}{*}{ Kategori } \\
\cline { 2 - 3 } & Rentang Nilai & Tahun & \\
\hline 1 & $-0,991$ s.d. $-0,579$ & 2015 & Kurang Baik \\
2 & $-0,578$ s.d. $-0,166$ & 2013,2017 & Cukup Baik \\
3 & $-0,165$ s.d. 0,247 & 2014 & Baik \\
4 & 0,248 s.d. 0,660 & 2012,2016 & Sangat Baik \\
\hline
\end{tabular}

Sumber: Data diolah, 2019

Uji beda Indeks Sharpe portofolio saham ukuran besar dan portofolio saham ukuran kecil sebagai berikut.

Tabel 10.

Mean dan Standar Deviasi Indeks Sharpe Portofolio Saham Ukuran BesarKecil

Group Statistics

Kelompok Portofolio Mean Std. Deviation

\begin{tabular}{llll}
\hline Indeks Sharpe & Portofolio Saham Ukuran Besar & .05783 & .611210 \\
& Portofolio Saham Ukuran Kecil & -.07183 & .633707 \\
\hline
\end{tabular}

Sumber: Data diolah, 2019

Tabel 10. menunjukkan bahwa rata-rata indeks Sharpe portofolio saham ukuran besar yaitu 0,05783 lebih tinggi dibandingkan dengan rata-rata portofolio saham ukuran kecil yaitu -0,07183. Rata-rata tersebut menunjukkan bahwa kinerja portofolio saham ukuran besar lebih baik dibandingkan dengan kinerja portofolio saham ukuran kecil.

Dilihat dari standar deviasi indeks Sharpe, standar deviasi portofolio saham ukuran kecil yaitu 0,633707 lebih tinggi dibandingkan dengan standar deviasi portofolio saham ukuran besar yaitu 0,611210 . Hal ini menunjukkan bahwa risiko portofolio saham ukuran kecil lebih tinggi dibandingkan dengan risiko portofolio saham ukuran besar. 
Perbedaan signifikansi indeks Sharpe portofolio saham ukuran besar dibandingkan dengan portofolio saham ukuran kecil dianalisis dengan menggunakan uji beda dua rata-rata independen. Pengujian dilakukan pada nilai indeks Sharpe portofolio saham ukuran besar dan portofolio saham ukuran kecil sebagai ukuran kinerja portofolio. Berdasarkan Tabel 11., menunjukkan nilai sig sebesar 0,726 lebih besar dari taraf sig sebesar 0,05. Hal ini menunjukkan bahwa tidak ada perbedaan yang signifikan antara indeks Sharpe portofolio saham ukuran besar dibandingkan dengan portofolio saham ukuran kecil.

Tabel 11.

Uji Beda Indeks Sharpe Portofolio Saham Ukuran Besar dan Portofolio Saham Ukuran Kecil

\begin{tabular}{|c|c|c|c|c|}
\hline \multicolumn{5}{|c|}{ Saham Ukuran Kecil } \\
\hline \multirow{2}{*}{\multicolumn{5}{|c|}{$\begin{array}{l}\text { Independent Samples Test } \\
\text { t-test for Equality of Means }\end{array}$}} \\
\hline & & & & \\
\hline & & Sig. (2- & $95 \%$ Confidence Interval of th & e Difference \\
\hline \multirow{3}{*}{ Indeks Sharpe } & & tailed) & Lower & $\begin{array}{l}\text { Upper } \\
930538\end{array}$ \\
\hline & $\begin{array}{l}\text { Equal variances } \\
\text { assumed }\end{array}$ & .726 & -.671205 & .930538 \\
\hline & $\begin{array}{l}\text { Equal variances } \\
\text { not assumed }\end{array}$ & .726 & -.671347 & .930680 \\
\hline
\end{tabular}

Sumber: Data diolah, 2019

Berdasarkan hasil uji beda dua rata-rata independen, indeks Sharpe menunjukkan tidak adanya perbedaan yang signifikan antara kinerja portofolio saham ukuran besar dibandingkan dengan portofolio saham ukuran kecil pada saham-saham Indeks Kompas 100 periode 2012-2017, sehingga hipotesis pada penelitian ini ditolak. Tidak adanya perbedaan yang signifikan kemungkinan terjadi akibat perusahaan besar yang tercermin dalam besaran total aset mengindikasikan adanya aset yang tidak produktif, sehingga semakin besar total aset akan mengindikasikan besar juga total aset yang tidak produktif. Hal ini menunjukkan tidak efektifnya pengelolaan perusahaan yang akan mengakibatkan penurunan kinerja perusahaan. Hal lain yang mungkin terjadi yaitu perusahaan berukuran kecil akan cenderung melakukan praktik perataan laba. Perataan laba merupakan upaya yang dilakukan oleh perusahaan untuk menstabilkan laba atau pendapatan perusahaan untuk mengurangi besarnya variabilitas dari satu periode ke periode lain sejauh yang dimungkinkan oleh prinsip akuntansi sehingga dinilai sebagai prestasi yang baik (Santoso et al., 2017)

Hasil penelitian ini juga menunjukkan bahwa kinerja portofolio saham ukuran besar lebih tinggi dibandingkan dengan portofolio saham ukuran kecil pada sahamsaham Indeks Kompas 100 periode 2012-2017. Hasil penelitian ini didukung oleh penelitian terdahulu yang dilakukan oleh Chiang (2016), Zaheri \& Barkhordary (2015), Latjuba \& Pasaribu (2013), dan Sorayaeni et al.(2012) yang menunjukkan bahwa kinerja portofolio saham ukuran besar lebih baik dibandingkan dengan portofolio saham ukuran kecil. Namun hasil penelitian ini juga berlawanan dengan penelitian yang dilakukan oleh Gautama (2017) di Nepal, Duy \& Phuoc (2016) di Vietnam, Pandey \& Sehgal (2015) di India, Haq \& Rashid (2014) di Pakistan, Twairesh (2014) di Arab Saudi, Ahmad et al. (2013) di Pakistan, Ye \& Li (2013) di China, dan Rutledge et al. (2008) di China yang menunjukkan bahwa kinerja 
portofolio saham ukuran kecil lebih baik dibandingkan dengan portofolio saham ukuran besar.

Perbedaan ini diperkirakan disebabkan karena karakteristik Pasar Modal Indonesia berbeda dengan karakteristik pasar modal negara lain. Hasil perhitungan indeks Sharpe yang sangat berfluktuasi mencerminkan tinggi-rendahnya return yang dihasilkan, hal ini disebabkan karena terjadinya perubahan harga saham perusahaan. Perubahan harga saham terjadi karena tersedianya informasi-informasi mengenai perusahaan tersebut. Ukuran perusahaan yang diproksikan melalui total aset dapat memberikan informasi bagi investor bahwa perusahaan dapat mengelola aktivitas bisnisnya dengan baik dan ini akan mempengaruhi sikap investor yang terlihat dari perubahan harga saham perusahaan. Oleh karena itu, faktor ini dapat memberikan pengaruh terhadap fluktuasi harga saham perusahaan di pasar modal. Apabila harga saham semakin naik, maka akan menambah ukuran perusahaan (Ardiansyah \& Isbanah, 2017).

Berdasarkan hasil uji beda, standar deviasi indeks Sharpe menunjukkan nilai standar deviasi portofolio saham ukuran kecil lebih tinggi dibandingkan dengan portofolio saham ukuran besar. Nilai standar deviasi ini menunjukkan bahwa portofolio saham ukuran kecil memiliki risiko yang lebih tinggi dibandingkan dengan portofolio saham ukuran besar. Standar deviasi mencerminkan total risiko portofolio yang mencakup risiko sistematis dan tidak sistematis serta berkaitan dengan ketidakpastian return yang diterima oleh investor. Risiko yang terkandung dalam portofolio seharusnya sebanding dengan return yang diberikan portofolio (high risk high return atau low risk low return). Pada penelitian ini, risiko yang terkandung dalam portofolio saham tidak sebanding dengan return yang diterima oleh investor.

Pada penelitian ini menunjukkan bahwa informasi-informasi yang masuk ke dalam pasar diserap dengan baik oleh investor dan pasar cenderung efisien, sehingga kesempatan yang dimiliki oleh investor sangat kecil untuk mendapatkan abnormal return. Perusahaan-perusahaan juga telah memberikan informasi terkait ukuran perusahaan yang tercermin pada laporan keuangan perusahaan yang dapat dimanfaatkan oleh investor dalam mengambil keputusan investasi.

Implikasi dari penelitian ini ada dua hal, yaitu implikasi teoritis dan implikasi praktis. Implikasi teoritis berhubungan dengan kontribusi empiris pada manajemen investasi tentang kinerja portofolio saham yang dibentuk berdasarkan ukuran perusahaan dengan indikator total aset sebagai pembentukan portofolio saham. Berdasarkan penelitian yang telah dilakukan, dapat diketahui bahwa penelitian ini mendukung beberapa teori ukuran perusahaan yang menyatakan bahwa perusahaan berukuran besar memiliki kinerja yang lebih baik atau memberikan return yang lebih tinggi dibandingkan perusahaan berukuran kecil. Hasil penelitian ini diharapkan dapat digunakan untuk menambah referensi dan ilmu pengetahuan tentang perhitungan kinerja portofolio saham. Implikasi praktis berhubungan dengan pengambilan keputusan yang akan dilakukan oleh investor.

Penelitian ini diharapkan dapat membantu investor dalam menentukan strategi yang akan digunakan dan juga sebagai bahan pertimbangan dalam mengambil keputusan investasi dengan melihat kinerja portofolio saham sehingga mendapatkan keuntungan dalam melakukan investasi. Investor dalam pembentukan 
portofolio saham berdasarkan ukuran perusahaan dapat memilih perusahaan besar maupun perusahaan kecil pada Indeks Kompas 100 karena tidak ada perbedaan yang signifikan antara kinerja portofolio saham ukuran besar dibandingkan dengan portofolio saham ukuran kecil.

Terdapat beberapa keterbatasan dari penelitian ini, yaitu keterbatasan variabel dan sampel penelitian. Penelitian ini hanya mengukur kinerja portofolio saham dengan satu alat ukur, yaitu indeks Sharpe dan sampel yang digunakan sedikit. Sebaiknya, penelitian selanjutnya dilakukan dengan menggunakan lebih dari satu alat ukur dan dengan sampel yang lebih banyak sehingga lebih bervariasi.

\section{SIMPULAN}

Berdasarkan hasil pengujian yang telah dilakukan, maka simpulan dari penelitian ini yaitu kinerja portofolio saham ukuran besar pada saham-saham Indeks Kompas 100 periode 2012-2017 yang diukur dengan indeks Sharpe tergolong sangat baik. Portofolio saham ukuran besar sebagian besar menunjukkan nilai yang positif selama periode 2012-2017.

Kinerja portofolio saham ukuran kecil pada saham-saham Indeks Kompas 100 periode 2012-2017 yang diukur dengan indeks Sharpe tergolong cukup baik. Portofolio saham ukuran kecil sebagian besar menunjukkan nilai yang negatif selama periode 2012-2017. Berdasarkan hasil uji beda dua rata-rata independen, indeks Sharpe menunjukkan tidak adanya perbedaan yang signifikan antara kinerja portofolio saham ukuran besar dibandingkan dengan portofolio saham ukuran kecil pada saham-saham Indeks Kompas 100 periode 2012-2017

Berdasarkan hasil penelitian dan simpulan yang diambil, maka terdapat beberapa saran yang dapat diajukan yaitu investor dalam melakukan pembentukan portofolio saham khususnya pada saham-saham Indeks Kompas 100 dapat memilih perusahaan besar maupun perusahaan kecil karena tidak ada perbedaan yang signifikan antara kinerja portofolio saham ukuran besar dibandingkan dengan portofolio saham ukuran kecil. Penelitian selanjutnya disarankan untuk menggunakan sampel yang lebih banyak untuk mengukur kinerja portofolio saham dan melakukan variasi yang berbeda pada sampel, seperti menggunakan sektor manufaktur atau sektor jasa.

\section{REFERENSI}

Ahmad, H., Fida, B. A., \& Zakaria, M. (2013). The Co-determinants of Capital Structure and Stock Returns: Evidence from the Karachi Stock Exchange. The Lahore Journal of Economics, 18(1), 81-92.

Alioui, S., Xiao, B., \& Chaibi, A. (2015). On The Impact Of Firm Size On Risk And Return: Fresh Evidence From The American Stock Market Over The Recent Years. The Journal of Applied Business Research, 31(1), 29-36.

Ardiansyah, I., \& Isbanah, Y. (2017). Analisis Pengaruh Deviden, Pertumbuhan Aset, Ukuran Perudahaan dan Leverage terhadap Volatilitas Harga Saham. Jurnal Riset Akuntansi Dan Keuangan, 5(3), 1565-1573. 
Chiang, G. (2016). Exploring the Transitional Behavior Among Value and Growth Stocks. Review of Quantitative Finance and Accounting, 47(3), 543-563.

Denziana, A., \& Monica, W. (2016). Analisis Ukuran Perusahaan dan Profitabilitas terhadap Nilai Perusahaan. Jurnal Akuntansi \& Keuangan, 7(2), 241-254.

Duy, N. T., \& Phuoc, N. P. H. (2016). The Relationship between Firm Sizes and Stock Returns of Service Sector in Ho Chi Minh City Stock Exchange. Review of European Studies, 8(4), 210-219.

Gautama, R. (2017). Impact of Firm Specific Variables on Stock Price Volatility and Stock Returns of Nepalese Commercial Banks. International Journal of Research in Business Studies and Management, 4(6), 33-44.

Handayani, D. W. (2014). Pengaruh Financial Leverage, Likuiditas, Pertumbuhan Aset, dan Ukuran Perusahaan terhadap Beta Saham Pada Perusahaan Manufaktur yang Terdaftar di Bursa Efek Indonesia. Jurnal Dinamika Akuntansi Dan Bisnis, 1(2), 169-182.

Haq, I. U., \& Rashid, K. (2014). Stock Market Efficiency and Size of the Firm: Empirical Evidence from Pakistan. Economics of Knowledge, 6(1), 10-31.

Latjuba, R. P., \& Pasaribu, R. B. F. (2013). Efek Bid-ask, Firm Size dan Likuiditas dalam Fenomena Price Reversal Saham Winner dan Loser Kelompok Entitas Indeks LQ-45 Periode 2009-2011 di Bursa Efek Indonesia. PESAT, 5(1), 308-316.

Pandey, A., \& Sehgal, S. (2015). Explaining Size Effect for Indian Stock Market. Journal of Financial Studies, 23(1), 45-68.

Pradnyaparamita, N. M. W. (2017). Pengujian Anomali Pasar January Effect pada Perusahaan LQ45 di Bursa Efek Indonesia. E-Jurnal Manajemen Unud, 6(7), 3513-3539.

Rutledge, R. W., Zhang, Z., \& Karim, K. (2008). Is There a Size Effect in the Pricing of Stocks in the Chinese Stock Markets?: The Case of Bull Versus Bear Markets. Journal of Managerial Finance, 15(2), 117-133.

Salamat, W. A. Al, \& Mustafa, H. H. H. (2016). The Impact of Capital Structure on Stock Return: Empirical Evidence from Amman Stock Exchange Title. International Journal of Business and Social Science, 7(9), 183-196.

Santoso, A., Puspitasari, D., \& Widyaswati, R. (2017). Pengaruh Manajemen Laba dan Ukuran Perusahaan terhadap Kinerja Perusahaan dengan Kualitas Audit sebagai Variabel Pemoderasi. Jurnal Administrasi Dan Bisnis, 11(1), 71-84.

Saputro, R. N., \& Badjra, I. B. (2016). Kinerja Portofolio Saham Berdasarkan Strategi Investasi Momentum pada Perusahaan Industri Manufaktur. EJurnal Manajemen Unud, 5(1), 623-649.

Sorayaeni, A., Emadi, R., \& Divkolaii, M. S. (2012). Investing of The Relationship of Assets on The Stock Returns of Accepted Companies in Tehran Valuable 
Sheet's Stock ExchangeInvesting of The Relationship of Assets on The Stock Returns of Accepted Companies in Tehran Valuable Sheet's Stock Exchange. Kuwait Chapter of Arabian Journal of Business and Management Review, $1(10), 22-26$.

Taha, R., \& Elgiziry, K. (2016). A Five-Factor Asset Pricing Model: Empirical Evidence from Egypt. International Journal of Business, 21(4), 342-372.

Tahir, S. H., Sabir, H. M., Alam, T., \& Ismail, A. (2013). Impact Of Firm's Characteristics On Stock Return: A Case Of Non-Financial Listed Companies In Pakistan. Asian Economic and Financial Review, 3(1), 51-61.

Twairesh, A. E. M. (2014). The Impact of Capital Structure on Firm's Performance Evidence from Saudi Arabia. Journal of Applied Finance \& Banking, 4(2), 183-193.

Yani, A. R., Suadarma, M., \& Prihatiningtias, Y. W. (2014). January Effect dan Size Effect pada Perusahaan yang Terdaftar di Bursa Efek Indonesia. Jurnal Manajemen Strategi Bisnis Dan Kewirausahaan, 4(2), 13-30.

Yanuarta, R. (2012). Anomali Size Effect di Bursa Efek Indonesia. Jurnal Kajian Manajemen Bisnis, 1(1), 39-58.

Ye, J., \& Li, W. F. (2013). Limits-To-Arbitrage And Asset Growth Anomaly In Chinese Stock Market. Nankai Business Review International, 4(3), 199-211.

Yulia, I. G. A. A., \& Artini, L. G. S. (2015). Dampak Pengumuman Deviden terhadap Abnormal Return pada Perusahaan LQ45 yang Terdaftar di Bursa Efek Indonesia. E-Jurnal Manajemen Unud, 4(12), 4449-4476.

Zaheri, F., \& Barkhordary, S. (2015). Relationship between Financial Characteristics of Companies in Cement Industry and Their Stock Returns in Tehran Stock Exchange. Research Journal of Recent Sciences, 4(8), 77-83. 